\title{
PERAN GURU DALAM IMPLEMENTASI KURIKULUM 2013 DI SMU NEGERI 1 WUNDULAKO KABUPATEN KOLAKA PROPINSI SULAWESI TENGGARA
}

\author{
Rahmawati M \\ Universitas Muhammadiyah Kendari \\ Rahma.wati937@yahoo.com
}

\begin{abstract}
ABSTRAK
Implementasi kurikulum 2013 diharapkan mampu menghasilkan insan produktif, kreatif, dan inovatif untuk bersaing dalam dunia internasional. Peran guru dalam implementasi kurukulum sangat penting guna meningkatkan mutu pendidikan dan menghasilkan output berkualitas serta mampu bersaing di Era-Globalisasi. Penelitian ini dilaksanakan di SMU Negeri 1 Wundulako Kabupaten Kolaka Propinsi Sulawesi Tenggara bertujuan untuk mendeskripsikan peran guru dalam implementasi kurikulum 2013. Informan utama dalam penelitian ini adalah wakil kepala sekolah bagian kurikulum, guru dan siswa. Berdasarkan hasil penelitian dan pembahasan dapat diketahui bahwa peran guru dalam implementasi kurikulum 2013 seperti; Peran guru dalam implementasi kurikulum 2013 di SMU Negeri 1 Wundulako secara umum sudah berjalan dengan baik, hal tersebut terlihat dalam perencanaan pembelajaran, pelaksanaan pembelajaran dan evaluasi pembelajaran. Perencanaan pembelajaran meliputi: penyusunan program tahunan, program semester, Silabus serta penyusunan RPP yang disesuaikan dengan aturan baru yang berpedoman pada silabus. Dalam pelaksanaan pembelajaran; tercakup dalam kegiatan pendahuluan, kegiatan inti, kegiatan penutup, pendekatan saintifik, penggunaan media pembelajaran, dan penggunaan metode pembelajaran yang bervariasi. Sedangkan evaluasi pembelajaran dilakukan dengan penilaian otentik untuk menilai mulai dari awal pembelajaran/input, proses, dan output pembelajaran. Penilaian dilakukan melalui beberapa tahap yaitu melalui pengamatan, penilaian diri sendiri, penilaian siswa dan penilaian antar siswa dengan menggunakan teknik penilaian yang bervariasi.
\end{abstract}

Kata Kunci: Peran Guru, Implementasi Kurikulum 2013

ABSTRACT

The implementation of the 2013 curriculum is expected to be able to produce productive, creative and innovative people to compete in the international world. The role of teachers in the implementation of curricula is very important in order to improve the quality of education and produce quality output and be able to compete in the Globalization Era. This research was carried out in Wundulako 1 Public High School Kolaka Regency, Southeast Sulawesi Province, which aimed to describe the role of the teacher in the 2013 curriculum implementation. The main informant in this study was the vice principal of the curriculum, teachers and students. Based on the results of the study and discussion it can be seen that the role of teachers in the implementation of the 2013 curriculum is like; The role of teachers in the implementation of the 2013 curriculum in Wundulako Public High School 1 has generally gone well, it is seen in the learning planning, the implementation of learning and evaluation of learning. Learning planning includes: annual program preparation, semester program, syllabus and preparation of RPP that are adjusted to the new rules that are guided by the syllabus. In the implementation of learning; included in preliminary activities, core activities, closing activities, scientific approach, use of learning media, and the use of various learning methods. While learning evaluation is done with authentic assessment to assess starting from the beginning of learning / input, process, and learning output. Assessment is carried out through several stages, namely through observation, self-assessment, student assessment and assessment among students using various assessment techniques.

Keywords: Teacher's Role, 2013 Curriculum Implementation 


\section{PENDAHULUAN}

Guru adalah tenaga profesional yang bertugas merencanakan dan melaksanakan proses pembelajaran, menilai hasil pembelajaran, melakukan bimbingan dan pelatihan serta melakukan penelitian dan pengabdian kepada masyarakat (UUD Sisdiknas, 2003). Guru merupakan pendidik yang merupakan orang dewasa yang bertanggung jawab memberikan pertolongan kepada anak didik dalam perkembangan baik jasmani maupun rohaninya. Agar tercapai tingkat kedewasaan mampu berdiri sendiri memenuhi tugasnya sebagai mahluk Tuhan, mahluk sosial dan mahluk individu yang mandiri (Gunawan, 2006: 17). Guru tidak hanya berperan sebagai penyampai materi pelajaran kepada peserta didik akan tetapi guru juga berperan sebagai pendidik, serta harus memposisikan diri secara aktif dan menempatkan kedudukannya sebagai tenaga professional, sesuai dengan tuntutan masyarakat yang tengah berkembang serta tuntutan Ilmu pengetahuan dan teknologi yang mendunia. Seorang pendidik harus memiliki kualifikasi akademik dan kompetensi sebagai agen pembelajaran, sehat jasmani dan rohani, serta memiliki kemampuan untuk mewujudkan tujuan Pendidikan Nasional (E. Mulyasa, 2003: 53).

Sanjaya

(2011:

mengemukakan bahwa peran utama seorang guru adalah menyampaikan ilmu pengetahuan sebagai warisan kebudayaan masa lalu yang dianggap berguna sehingga harus dilestarikan. Pengertian lain tentang peran guru yang tepat dalam pengembangan dan penyampaian pembelajaran adalah guru memilih dan mengubah materi pembelajaran yang telah ada agar sesuai dengan kebutuhan belajar peserta didik untuk mencapai KD dan KI yang telah ditetapkan dalam standar isi Sudjimat, (2014: 22).

Keberhasilan implementtasi kurikulum perlu ditunjang oleh guru berkualitas yang mampu menganalisis, menafsirkan, dan mengaktualisasikan informasi yang ada dalam dokumen kurikulum kedalam pembelajaran, bagi guru, kurikulum berfungsi sebagai pedoman dalam pelaksanaan proses pembelajaran. Oleh karena itu, bagaimanapun idealnya kurikulum tanpa ditunjang oleh kemampuan guru untuk mengaktualisasikan dan mengimplementasikannya, maka kurikulum tidak akan bermakna sama sekali dan pembelajaran tidak akan efektif. Sebagai kunci keberhasilan implementasi kurikulum, guru berperan dalam tatanam pembelajaran. Menurut sanjaya (2008: 28) bahwa terdapat empat peran guru dalam pengembangan kurikulum yaitu:

1. Guru sebagai implementers

Peran ini, guru hanya bertugas untuk melaksanakan kurikulum yang sudah ada. 
Sebagai implementers guru hanya menerima sebagai kebijkan pengembang kurikulum. Guru tidak memiliki ruang untuk menentukan isi kurikulum maupun menentukan target kurikulum. Peran guru hanya terbatas pada menjalankan kurikulum yang telah disusun. Semua isi kurikulum baik tujuan, materi, strategi, media, sumber belajar, serta evaluasi, waktu, dan semua komponennya telah ditentukan oleh pengembang kurikulum. Guru hanya berperan sebagai tenaga teknis saja yang berusaha menjalankan apa yang tertuang dalam dokumen kurikulum.

Peran ini pernah dilaksanakan di Indonesia saat sebelum reformasi, yaitu guru sebagai implementator kebijakan kurikulum yang disusun secara terpusat, dituangkan dalam GarisGaris Besar Program Pengajaran (GBPP). Dalam GBPP yang berbentuk matrik telah ditentukan dari mulai tujuan yang harus dicapai, materi pelajaran yang harus disampaikan, cara yang harus dilakukan, hingga alokasi waktu pelaksanaan. Dalam pengembangan kurikulum guru dianggap sebagai tenaga teknis yang hanya bertanggung jawab dalam mengimplementasikan berbagai ketentuan yang ada. Kurikulum bersifat seragam, sehingga apa yang dilakukan guru di Indonesia bagian timur sama dengan apa yang dilakukan guru di Indonesia bagian barat. Dengan terbatasnya peran guru di sini, maka kreatifitas guru dan inovasi guru dalam merekayasa pembelajaran tidak berkembang. Guru tidak ada motivasi untuk melakukan berbagai pembaruan.

2. Guru sebagai adafters

Pada peran ini, guru selain tenaga teknis dai kurikulum yang telah disusun, juga melakukan fungsi lain yaitu penyelas kurikulum dengan karakteristikkebutuhan siswa dan kebutuhan daerah. Guru sebagai adafters memiliki kewenangan lebih untuk mneyesuaikan kurikulum yang sudah ada dengan karakteristik sekolah, peserta didik, materi, maupun kebutuhan local. Pengembang kurikulum telah menentukan standar minimal yang harus dicapai, kemudian pengembangan selanjutnya serta implementasinya diserahkan kepada guru masing-masing.

3. Guru sebagai developers

Guru sebagai developers bukan hanya memiliki peran dalam menentukan tujuan dan isi pelajaran yang akan disampaikan, akan tetapi juga dapat menentukan strategi yang akan dikembangkan serta bagaimana mengukur keberhasilannya melalui pemilihan alat evaluasi untuk pencapaian hasil belajar 
4. Guru sebagai researchers atau peneliti

Dalam melaksanakan perannya sebagai peneliti, guru memiliki tanggung jawab untuk menguji berbagai komponen kurikulum, menguji efektifitas program, menguji strategi dan model pembelajaran, dan semua hal yang berkaitan dengan pembelajaran. Guru juga melakukan pengumpulan data keberhasilan siswa. Peran guru sebagai peneliti nampak pada kebijakan guru yang harus melakukan penelitian tindakan kelas (PTK).

Implementasi merupakan suatu pengaktualisasian ide, konsep kebijakan atau inovasi yang mendasari suatu program dalam tindakan praktis yang logis dan nyata di lapangan. Susilo (2007: 174). Penerapan kurikulum atau implementasi kurikulum adalah pelaksanaan program kurikulum yang telah dikembangkan dalam tahap sebelumnya kemudian diujicobakan dengan pelaksanaan dan pengelolaan, sambil senantiasa dilakukan dengan penyesuaian terhadap situasi lapangan dan karakteristik peserta didik, baik perkembangan intelektual, emosional, serta fisiknya. Hamalik (2007: 238).

Setiap kurikulum memiliki cara implementasi atau penerapan yang berbeda namun tujuannya sama yaitu untuk menghasilkan manusia Indonesia pancasilais dan itu sangat diharapkan kepada guru untuk bekerja ekstra dan professional dalam mendidik anak didik. Guru harus merancang pembelajaran efektif dan bermakna (menyenangkan), mengorganisasikan pembelajaran, memilih pendekatan pembelajaran yang tepat, menetukan prosedur pembelajaran dan pembentukan kompetensi secara efektif serta menetakan criteria keberhasilan. E. Mulyasa (2013: 27).

Pengimplementasian kurikulum harus dilihat dari situasi dan kondisi sekolah yang menganjurkan semua elemen berperan aktif dalam mencerdaskan dan memberikan pendidikan karakter anak didik yang akuntabel dan berperilaku pancasilais. Pendidikan karakter merupakan upaya menanamkan nilainilai social, etika, moral atau budi pekerti dengan tujuan terbentuknya karakter anak didik yang baik.

Menurut Anang Tjahjono (2013: 1), berasumsi bahwa "Kurikulum 2013 merupakan kurikulum yang berbasis pada pengembangan kompetensi siswa. Kurikulum berbasis kompetensi ("outcomes-based curriculum") yaitu pengembangan kurikulum yang diarahkan pada pencapaian kompetensi seperti yang telah dirumuskan dalam Standar Kompetensi Lulusan." Pengertian tersebut dapat diasumsikan bahwa Kurikulum 2013 merupakan 
pengembangan kurikulum yang berfokus pada kompetensi dan karakter siswa yang dicapainya melalui pengalaman belajarnya yang telah dirumuskan dalam Standar Kompetensi Lulusan. Kurikulum 2013 diarahkan untuk mengembangkan pengetahuan, pemahaman, kemampuan, nilai, sikap, dan minat siswa agar dapat melakukan sesuatu dalam bentuk kemahiran, ketepatan, dan keberhasilan dengan penuh tanggung jawab.

Tujuan diselenggarakannya Kurikulum 2013 adalah "untuk mempersiapkan manusia Indonesia agar memiliki kemampuan hidup sebagai pribadi dan warga Negara yang beriman, produktif, kreatif, inovatif, dan afektif serta mampu berkontribusi pada kehidupan bermasyarakat, berbangsa, bernegara, dan peradaban dunia", seperti tercantum dalam Peraturan Menteri Pendidikan dan Kebudayaan Nomor 70 Tahun 2013 tentang Kerangka Dasar dan Struktur Kurikulum Sekolah Menengah Kejuruan/Madrasah Aliyah Kejuruan. Memahami tujuan tersebut, melalui pengalaman belajar, keterampilan, dan dasar-dasar pengetahuan yang diberikan, Kurikulum 2013 yang berbasis kompetensi dan karakter ini ditujukan untuk menciptakan tamatan yang kompeten dan cerdas sehingga dapat mengembangkan identitas budaya dan bangsanya serta dapat membangun integritas sosial dalam mewujudkan karakteristik nasional bangsa.

Berdasarkan observasi awal yang dilakukan di SMU Negeri 1 Wundulako Kabupaten Kolaka Propinsi Sulawesi Tenggara, bahwa pembelajaran dengan menggunakan Kurikulum 2013 belum dapat dilaksanakan dengan baik, karena adanya beberapa kendala yang dialami oleh para guru. Salah satu guru mengungkapkan bahwa pemahaman guru terhadap esensi Kurikulum 2013 masih kurang sehingga penerapan kurikulum 2013 di dalam kelas kurang maksimal. Selain itu, guru menyebutkan bahwa Kurikulum 2013 sulit untuk diterapkan terlebih lagi jika dilihat dari kondisi sekolah yang kelengkapan sarana belum memadai.

\section{METODE PENELITIAN}

Jenis penelitian ini adalah jenis penelitian deskriptif kualitatif, sebab penelitian bertujuan untuk mendeskripsikan peran guru dalam implementasi kurikulum 2013 di SMU Negeri 1 Wundulako Kabupaten Kolaka Propinsi Sulawesi Tenggara. Data deskriptif berupa kata-kata tertulis atau lisan dari informan yaitu guru dan siswa dengan perilaku yang diamati.

Dalam kegiatan pengumpulan data telah menggunakan metode Field Research, yaitu metode pengumpulan data dengan mengadakan penelitian langsung di 
lapangan. Dalam hal ini penulis menempuh teknik sebagai berikut:

1. Observasi adalah dasar semua ilmu pengetahuan. Para ilmuan hanya dapat bekerja berdasarkan data, yaitu fakta mengenai dunia kenyataan yang diperoleh melaui observasi. Penelitian ini mengunakan observasi partisipatif yaitu peneliti ikut terlibat dengan kegiatan sehari-hari orang yang sedang diamati atau yang digunakan sebagai sumber data penelitian Nasution dalam (Sugiyono, 2009: 310).

2. Wawancara adalah merupakan pertemuan dua orang untuk bertukar informasi dan ide melalui tanya jawab, sehingga dapat dikonstruksikan makna dalam sebuah topik. Esterberg dalam Sugiyono (2009: 317). Wawancara digunakan sebagai teknik mencari data atau informasi berupa ucapan, pikiran, gagasan, dan kesadaran social. Melalui wawancara diharapkan responden memberikan informasi secara mendalam tentang peran guru dalam implementasi kurikulum 2013 di SMU Negeri 1 Wundulako Kabupaten Kolaka Propinsi Sulawesi Tenggara.

3. Dokumentasi adalah hasil penelitian akan dapat dipercaya apabila didukung oleh foto-foto atau kerya tulis akademik dan seni yang telah ada (Sugiyono, 2009: 329). Dokumentasi digunakan dalam penelitian mencari data- data mengenai hal-hal yang berhubungan dengan peran guru dalam implementasi kurikulum 2013 di SMU Negeri 1 Wundulako Kabupaten Kolaka Propinsi Sulawesi Tenggara.

Teknik analisis data yang dipergunakan dalam penelitian ini adalah kualitatif deskriptif yang mana analisis datanya dilakukan dengan cara non statistik, yaitu penelitian yang dilakukan dengan menggambarkan data yang diperoleh dengan kata-kata atau kalimat yang dipisahkan dalam kategori-kategori untuk memperoleh kesimpulan. Hal ini sebagaimana yang dikatakan oleh Nasution (2002: 128) bahwa data kualitatif terdiri dari kata-kata bukan angka-angka dimana mendeskripsikan memerlukan interpretasi sehingga diketahui makna dari kata-kata tersebut. Selanjutnya digambarkan sebagai berikut:

1. Pengumpulan Data: Pengumpulan data yang digunakan dalam penelitian ini dimaksudkan untuk mencatat semua data secara objektif dan mandalam dengan tanpa mengubah kondisi dilapangan.

2. Reduksi Data: Data yang diperoleh dilapangan jumlahnya sangat banyak, sangat rumit dan tidak teratur. Untuk itu perlulah mencatat hasil data yang ditemukan dilapngan secara teliti dan terperinci yang kemudian 
dapat memudahkan dalam pemimlihan data. Data-data yang sudah dikumpulkan, dicatat secara teperinci dan teliti tersebut kemudian direduksi, yang artinya data dipilih dan dipusatkan perhatiannya kepada fokus masalah penelitian sehingga konsistensi penelitian tetap terjaga.

3. Penyajian Data: Setelah data direduksi sesuai dengan kode dan telah terhubung satu sama lain, langkah selanjutnya adalah dengan menyajikan data. Dengan menyajikan data, maka peneliti akan mudah untuk memahami apa yang terjadi, merencanakan apa yang akan dilakukan selanjutnya berdasarkan apa yang sudah dipahami. Data yang disajikan bisa berupa uraian singkat, bagan, hubungan antara kategori dan sebagainya.

4. Penarikan Kesimpulan: Ketika data pertama yang diambil dapat menjawab pertanyaan penelitian yang didukung oleh bukti-bukti yang kuat maka hal tersebut bisa dijadikan acuan sebagai kesimpulan awal penelitian, yang nanti akan dilanjutkan oleh pengambilan data selanjutnya dan terbukti data tersebut konsisten menjawab pertanyaan penelitian mengenai peran guru dalam implementasi kurikulum di sekolah maka dapat ditarik kesimpulan yang kredibel selama penelitian berlangsung

\section{HASIL PENELITIAN}

Berdasarkan hasil penelitian yang diperoleh melalui wawancara oleh informan bahwa penerapan kurikulum 2013 merupakan aktualisasi kurikulum dalam pembelajaran dan pembentukan kompetensi serta karakter peserta didik. Penerapan atau implementasi kurikulum 2013 menuntut kerja sama yang optimal diantara para guru, sehingga memerlukan pembelajaran berbentuk tim, dan menuntut kerja sama yang kompak diantara para anggota tim demi tercapainya tujuan pendidikan. Penerapan atau implementasi kurikulum 2013 di dalam proses pembelajarannya meliputi tiga aspek yaitu implementasi pembelajaran, pelaksanaan pembelajaran, dan evaluasi pembelajaran. Berdasarkan hasil penelitian Peran guru dalam implementasi kurikulum 2013 di SMU Negeri 1 Wundulako Kabupaten Kolaka Propinsi Sulawesi Tenggara dapat dideskripsikan sebagai berikut:

1. Peran Guru dalam Perencanaan Pembelajaran Kurikulum 2013 di SMU Negeri 1 Wundulako Kabupaten Kolaka Propinsi Sulawesi Tenggara

Kurikulum digunakan
sebagai dalam
penyelenggaraan pendidikan dan
merupakan salah satu indikator
mutu pendidikan. Dalam
penerapan kurikulum 2013 ada
beberapa perencanaan yang
dilakukan guru di kelas sebelum


mengajar yaitu: membuat program tahunan, program smester, silabus, dan RPP yang disesuaikan dengan aturan yang baru. Program tahunan merupakan program umum setiap mata pelajaran yang akan dilakukan guru mata pelajaran selama satu tahun pelajaran untuk setiap kelas, program ini dibuat sebelum tahun ajaran baru dimulai. Program semester ini berisikan garis-garis besar mengenai hal-hal yang hendak dilaksanakan dan dicapai dalam satu semester. Program semester ini merupakan penjabaran dari program tahunan. Silabus digunakan sebagai acuan dalam pengembangan rencana pelaksanaan pembelajaran. RPP merupakan rencana kegiatan pembelajaran tatap muka untuk satu pertemuan. RPP dikembangkan dari silabus dengan memperhatikan buku peserta didik dan buku guru yang sudah disiapkan oleh Kementerian Pendidikan dan Kebudayaan.

Rencana Pelaksanaan Pembelajaran meliputi: penyusunan rencana pelaksanaan dan penyiapan media dan sumber belajar, perangkat penilaian pembelajaran, dan skenario pembelajaran. Pelaksanaan pembelajaran dapat disusun berdasarkan kebutuhan dalam jangka waktu tertentu sesuai dengan keinginan pembuat perencanaan dan dapat dilaksanakan dengan mudah dan tepat sasaran.

Berdasarkan hasil wawancara di lapangan, dapat disimpulkan bahwa perencanaan pembelajaran merupakan suatu proses mempersiapkan langkahlangkah yang akan dilaksanakan untuk mencapai tujuan yang sudah ditetapkan meliputi program tahunan, program semester, silabus, dan RPP yang disesuaikan dengan aturan yang baru. Langkah-langkah yang dilakukan guru dalam menyusun perencanaan pembelajaran berupa RPP adalah menetapkan/memilih materi, metode, media pembelajaran, dan lain sebagainya.

2. Peran guru dalam pelaksanaan pembelajaran Kurikulum 2013 Di SMU Negeri 1 Wundulako Kabupaten Kolaka Propinsi Sulawesi Tenggara

Guru merupakan figur utama dalam pelaksanaaan pembelajaran. keberhasilan suatu kurikulum yang diterapkan pada pembelajaran tidak terlepas dari peran. seorang guru di dalamnya. Dalam pengimplementasikan kurikulum di kegiatan pembelajaran, guru harus memahami dan menguasai isi yang tertuang dalam kurikulum tersebut, untuk itu guru harus mempersiapkan diri terhadap 
perubahan

kurikulum

pembelajaran.

Berdasarkan hasil observasi, wawancara dan dokumentasi yang dilaksanakan peneliti terhadap peran guru dalam implementasi kurikulum 2013 di SMU Negeri 1 Wundulako secara umum sudah berjalan dengan baik. Hal tersebut terlihat dalam proses pembelajaran di mana guru melakukan kegiatan pendahuluan, kegiatan inti, dan kegiatan penutup. Semua yang dilakukan guru merupakan implementasi dari RPP yang telah dibuat guru. Dalam hal ini, guru sudah melaksanakan pembelajaran sesuai dengan panduan. Dalam pelaksanaannya, guru sudah melakukan pendekatan saintifik yakni mengamati, menanya, mengumpulkan informasi, mengasosiasi, dan mengomunikasikan.

Menggunakan berbagai metode yang bervariasi dalam pembelajaran dengan menyesuaikan materi yang akan disajikan guna untuk meningkatkan keaktifan siswa dalam belajar; guru-guru SMU Negeri 1 Wundulako juga menggunakan media pembelajaran yang bervariasi sesuai dengan karakter mata pelajaran untuk meningkatkan keaktifan siswa dalam mengikuti pembelajaran; memilih sumber belajar yang sesuai dan cocok diterapkan dalam proses pembelajaran. Sumber materipun yang digunakan dalam mengajar juga beragam, selain dari buku pegangan siswa dan guru, guru juga mengambil sumber dari internet jika diperlukan. Selain itu dalam pelaksanaan pembelajaran guru guru juga dituntut untuk mampu menjadi fasilitator.

3. Peran Guru dalam Evaluasi Pembelajaran Kurikulum 2013 Di SMU Negeri 1 Wundulako Kabupaten Kolaka Propinsi Sulawesi Tenggara

Evaluasi merupakan suatu penilaian terhadap suatu kinerja yang sudah dikerjakan. Teknis atau cara yang digunakan dalam evaluasi untuk mengetahui keberhasilan dalam suatu pembelajaran. Evaluasi bertujuan untuk mengetahui apakah sesuatu yang diterapkan berjalan dengan baik atau tidak dan sejauh mana penerapan tersebut berjalan khususnya dalam penerapan dan pelaksanaan kurikulum 2013, dari hasil wawancara diketahui bahwa guru selalu melakukan evaluasi yang bertujuan untuk mengetahui tingkat keberhasilan setelah melakukan proses pembelajaran terhadap siswa. Guru-guru melaksanakan evaluasi disetiap akhir mata pelajaran, akhir materi pembelajaran juga evaluasi harian berdasarkan pada mata pelajaran yang telah diajarkan. Untuk 
evaluasi dilakukan melalui tes secara lisan dan tes tertulis. Penilaian yang dilakukan dalam kurikulum 2013 yaitu dengan penilaian otentik yaitu merupakan penilaian komprehensif yang dilakukan untuk menilai mulai dari awal pembelajaran/input, proses, dan output pembelajaran. Penilaian dalam evaluasi melalui pengamatan, penilaian diri sendiri, penilaian siswa dan penilaian antar siswa yaitu menilai dengan menggunakan instrument daftar cek dan disertai. Secara keseluruhan guru telah melaksanakan evaluasi pembelajaran. Dimana akan bertujuan untuk mengetahui keberhasilan siswa dalam menerima pelajaran di dalam kelas yang meliputi penilaian aspek pengetahuan, aspek sikap spiritual dan sosial, dan aspek keterampilan.

Hasil wawancara di atas
menunjukkan bahwa guru
melakukan evaluasi untuk
mengetahui apakah tujuan yang telah dirumuskan tercapai atau belum, dan apakah materi yang diajarkan sudah cukup tepat atau belum, untuk mengetahui semua itu dilakukan evaluasi atau penilaian, penilaian yang dilakukan oleh guru mencakup penilaian sikap, pengetahuan, dan keterampilan. Penilaian dilakukan melalui beberapa tahap yaitu mealui pengamatan, penilaian diri sendiri, penilaian siswa dan penilaian antar siswa. Penilaian dilakukan dengan menggunakan instrument yaitu untuk penilaian dengan observasi, penilaian diri sendiri, penilaian siswa dan penilaian antar siswa yaitu dengan menggunakan instrument daftar cek (rating scale) yang disertai dengan rubrik penilaian.

\section{PEMBAHASAN HASIL PENELITIAN}

1. Peran Guru Dalam Perencanaan Pembelajaran Di SMU Negeri 1 Wundulako Kabupaten Kolaka Propinsi Sulawesi Tenggara

Seperti halnya pembelajaran pada umumnya, pembelajaran dalam kurikulum 2013 dalam persiapannya juga perlu membuat seluruh program pembelajaran. seperti: prota, promes, Silabus, RPP. Langkah-langkah yang dilakukan guru dalam menyusun perencanaan pembelajaran berupa RPP. Di dalam mengkaji buku guru, kegiatan yang dilakukan guru adalah menganalisis SKL, KI, KD, Indikator. Untuk KD dan indikator yang tercantum dalam buku guru menyesuaikan dengan strategi yang akan digunakan nantinya.

Melaksanakan program pada dasarnya mengimplementasikan program yang telah disusun dalam proses belajar mengajar di kelas. Hal ini berarti keberhasilan pelaksanaan pembelajaraan sangat bergantung dari kualitas 
perencanaan pembelajaran yang telah disusun, terutama silabus dan RPP.

\section{Berdasarkan}

hasil

wawancara dan pengamatan yang dilakukan terkait perencanaan pembelajaran kurikulum 2013, yang dipersiapkan guru antara lain program tahunan, program semester, Silabus dan RPP yang disesuaikan dengan peraturan yang baru. Langkah-langkah yang dilakukan guru dalam menyusun perencanaan pembelajaran berupa RPP adalah menetapkan/memilih mata pelajaran, lalu mengkaji buku guru. Di dalam mengkaji buku guru, kegiatan yang dilakukan guru adalah menganalisis SKL, KI, $K D$, Indikator. Untuk KD dan indikator yang tercantum dalam buku guru dengan disesuaikan strategi dan media pembelajaran. Hal tersebut sejalan dengan apa yang dikemukakan Sumarno, (2014); Partin (2009) yang menyatakan bahwa guru harus menyusun perangkat pembelajaran dengan baik agar hasil pembelajaran sesuai dengan keluaran yang diharapkan. Perencanaan pembelajaran akan mempermudah dalam menentukan target ketercapaian sebelum pelaksanaan dilakukan, menentukan langkah-langkah yang harus dijalankan selama pelaksanaan, serta mempermudah evaluasi setelah proses pelaksanaan (Harjanto, 2003).

2. Peran guru dalam Pelaksanaan Pembelajaran Kurikulum 2013 di SMU Negeri 1 Wundulako Kabupaten Kolaka Propinsi Sulawesi Tenggara

Pelaksanaan pembelajaran yang dilaksanakan di SMU Negeri 1 Wundulako berdasarkan hasil observasi, wawancara dan dokumentasi secara umum sudah disesuaikan dengan rencana pelaksanaan pembelajaran (RPP) yang disusun sebelumnya, hal tersebut dilakukakan untuk mengetahui kekurangan dan kelebihan selama proses pembelajaran. Dengan berpedoman pada RPP, guru dapat mengajar secara sistematis, tanpa khawatir keluar dari tujuan, ruang lingkup materi, strategi pembelajaran, atau keluar dari sistem evaluasi yang seharusnya dilakukan.

Perencanaan adalah kegiatan menyusun langkahlangkah yang akan dilaksanakan untuk mencapai tujuan yang telah ditentukan. Namun yang lebih utama adalah perencanaan yang dibuat harus dilaksanakan dengan mudah dan tepat sasaran, Toth (2012: 195-216). Dalam merencanakan kegiatan yang hendak dilaksanakan dalam hal ini pelaksanaan pembelajaran seorang guru harus mampu 
menyusun perencanaan yang mudah untuk direalisasikan, perencanaan tersebut harus tepat sasaran sehingga dalam pelaksnaannya berjalan dengan baik sesuai dengan tujuan yang ingin dicapai. Pelaksanaan pembelajaran kurikulum 2013 di SMU Negeri 1 Wundulako tertuang dalam beberapa aspek yang terdiri dari; kegiatan pendahuluan, kegiatan inti, kegiatan penutup, pendekatan saintifik, dan media pembelajaran, serta metode pembelajaran.

3. Peran Guru dalam Evaluasi Pembelajaran Kurikulum 2013 di SMU Negeri 1 Wundulako Propinsi Sulawesi Tenggara

Evaluasi

merupakan

kegiatan penilaian terhadap pencapaian kompetensi bagi peserta didik. E. Mulyasa (2013: 69-70). Evaluasi bertujuan untuk mengetahui apakah sesuatu yang diterapkan berjalan dengan baik atau tidak dan sejauh mana penerapan tersebut berjalan khususnya dalam penerapan dan pelaksanaan, pendekatan saintifik, media dan metode di dalam kurikulum 2013.

Guru dalam melakukan penilaian menekankan kepada tiga aspek yaitu aspek pengetahuan melalui pemberian tes tulis dan tertulis, sedangkan aspek keterampilan yaitu dengan menilai dari unjuk kerja (performance) siswa. Sedangkan pada aspek sikap dilakukan melalui pengamatan langsung pada setiap perilaku siswa selama pembelajaran berlangsung. Penilaian yang dilakukan yaitu dengan penilaian otentik yaitu merupakan penilaian komprehensif yang dilakukan untuk menilai mulai dari awal pembelajaran/input, proses, dan output pembelajaran. Penilaian dilakukan melalui beberapa tahap yaitu melalui pengamatan, penilaian diri sendiri, penilaian siswa dan penilaian antar siswa. Pada kurikulum 2013 menggunakan penilaian otentik. Penilaian otentik dilakukan untuk mengukur proses pembelajaran dan hasil belajar siswa secara menyeluruh (Taufina, 2009). Penilaian dilakukan dengan menggunakan instrument yaitu untuk penilaian dengan observasi, penilaian diri sendiri, penilaian siswa dan penilaian antar siswa yaitu dengan menggunakan instrument daftar cek (rating scale) yang disertai dengan rubrik penilaian. Sifat penilaian otentik yang komprehensif juga dapat membentuk unsur-unsur metekognisi dalam diri peserta didik seperti kemampuan mengambil resiko, kreatif, mengembangkan kemampuan berpikir tingkat tinggi dan berpikir kreatif, tanggung jawab terhadap 
tugas dan karya, dan rasa kepemilikan.

\section{KESIMPULAN}

Peran guru dalam implementasi kurikulum 2013 di SMU Negeri Wundulako secara umum sudah berajalan dengan baik, hal tersebut dapat terlihat dalam perencanaan pembelajaran, pelaksanaan pembelajaran dan evaluasi pembelajaran.

Perencanaan pembelajaran meliputi: penyusunan program tahunan, program semester, Silabus serta penyusunan RPP yang disesuaikan dengan aturan baru yang berpedoman pada silabus. Dalam pelaksanaan pembelajaran; tercakup dalam kegiatan pendahuluan, kegiatan inti, kegiatan penutup, pendekatan saintifik, penggunaan media pembelajaran, dan penggunaan metode pembelajaran yang bervariasi. Sedangkan evaluasi pembelajaran dilakukan dengan penilaian otentik untuk menilai mulai dari awal pembelajaran/input, proses, dan output pembelajaran. Penilaian dilakukan melalui beberapa tahap yaitu melalui pengamatan, penilaian diri sendiri, penilaian siswa dan penilaian antar siswa dengan menggunakan teknik penilaian yang bervariasi.

\section{DAFTAR PUSTAKA}

Penelitian

2010. Metode Pendekatan
Pendidikan

Kuantitatif,
Kualitatif,dan $R \& D$. Bandung: Alfabeta.

Pembelajaran.

Kencana. Hal 52

2013. Peraturan

Menteri Pendidikan dan Kebudayaan Republik Indonesia Nomor 70 Tahun 2013 tentang Kerangka Dasar dan Struktur Kurikulum Sekolah Dasar Menengah Kejuruan/Madrasah Aliyah Kejuruan. Jakarta.

E. Mulyasa. 2013. Pengembangan dan Implementasi Kurikulum 2013. Bandung: PT . Remaja Rosdakarya.

Harjanto. 2003. Perencanaan Pengajaran. Jakarta: PT Rineka Cipta.

Hidayat, S. 2013. Pengembangan Kurikulum Baru. Bandung: PT. Remaja Rosdakarya

Kwartolo, Yuli. 2002. Catatan Kritis tentang Kurikulum Berbasis Kompetensi. Jurnal Pendidikan Penabur. Vol. 1. Eds 1: 1-9.

Martinis Yamin. 2007. Profesionalisasi guru dan implementasi kurikulum KTSP. Jakarta: Gaung Persada Press

Menteri Pendidikan dan Kebudayaan Republik Indonesia. 2013. Peraturan Menteri Pendidikan dan Kebudayaan Republik Indonesia Nomor 65 Tahun 2013. tentang Standar Proses Pendidikan Dasar dan Menengah. Jakarta.

Partin, R. 2009. The Classroom Teacher's Survival Guide (3th ed). San Fransisco: John Wiley\&Sons. 
Peraturan Pemerintah. 2013. Peraturan Pemerintah No. 32 Tahun 2013 tentang Perubahan Atas Peraturan Pemerintah No. 19 Tahun 2005 tentang Standar Nasional Pendidikan. Jakarta.

Rendah SD. Jurnal IImiah IImu Pendidikan. 9(1): 113-120.

Sanjaya. Wina. 2012. Strategi pembelajaran beriorentasi standar proses pendidikan. Jakarta: Kencana Prenada Media Group

Sudjimat, Dwi. A. 2014. Perencanaan Pembelajaran Kejuruan. Malang: UM Press

Sugiyono. 2009. Metode Penelitian Pendidikan Pendekatan Kuantitatif, Kualitatif,dan R \& D. Bandung: Alfabeta.

Taufina. 2009. Authentic Assessment dalam Pembelajaran Bahasa Indonesia di Kelas

Toht, Peter. 2012. Learning Strategies and Style in Vocational Education. Acta Polytechnica Hungarica. Vol. 9, Eds 3: 195216.
Undang-undang Nomor 20 Tahun 2003 tentang Sistem Pendidikan Nasional. 2003. Jakarta: Departemen Pendidikan Nasional.

